\title{
The Influence of Strategic Leadership and Organizational Learning on Organizational Performance with Organizational Citizenship Behavior as an Intervening Variable
}

\author{
Fernando Dias Gusmão ${ }^{1}$, Budiman Christiananta ${ }^{2}$, Lena Ellitan ${ }^{3}$ \\ ${ }^{1,2,3}$ Universitas Katolik Widya Mandala Surabaya, School of Post Graduate,Surabaya, Indonesia
}

\begin{abstract}
This study aimed to analyze the influence of Strategic Leadership and Organizational Learning, on Organizational Performance with Organizational Citizenship Behavior as an intervening variable in the Ministry of Government of Timor-Leste. Research will be conducted on the Director-General of all Government Ministries as many as 18 Ministries and using 40 people as respondents. Data analysis using Partial Least Square (PLS). The results of the study showed with the approach of Partial Least Square (PLS) that the model of Organizational Performance is fit based on the criteria of R2, Q2. Strategic Leadership, Organizational Learning, Organizational Citizenship Behavior and Organizational Performance is valid and reliable. Strategic Leadership, Organizational Learning, affect Organizational Citizenship Behavior. Strategic Leadership, Organizational Learning affects Organizational Performance. Organizational Citizenship Behavior affects Organizational Performance. Strategic Leadership with indicator the ability to cohesion and sense of belonging and visionary provides the dominant influence on Organizational Performance. Next, Organizational Citizenship Behavior with indicator Conscientiousness effect is not directly on the largest Organizational Learning to Organizational Performance.

Keywords: Strategic Leadership, Organizational Learning, Organizational Citizenship Behavior, Organizational Performance.
\end{abstract}

\section{Introduction}

Each organization will attempt to achieve its goals. This condition is a logical consequence of the establishment of an organization. Timor-Leste Government, as an organization, also tries to realize their goals. On that account, every Government Ministry in Timor Leste should have the right strategy to encounter any challenge and provides the correct solution to the existing problems.

The role of leadership is very strategic and significant for an organization as a determinant factor in achieving mission, vision and organizational goals successfully. Waterman and Peter [1] stated that leaderships are related to the ability to direct and cooperate with other parties. Wright [2] stated that the need of leadership for strategic implementation would require important factors, i.e.: strategic leadership, power, and the ability to create a conducive organizational culture in strategic implementation.

Garvin [3] stated organizational learning as an organizational skill to create, obtain, interpret, transfer and share knowledge, aiming to modify the behavior to describe knowledge and new insight.
The indicators for organizational learning were developed by Senge [4], consisting of system thinking, mental mode, personality control, team learning and shared vision.

In organizational behavior, good behavior of organization members, often known as Organizational Citizenship Behavior (OCB), is important to be achieved because this will give a positive contribution to the quality of work and performance of the organization. Aldag and Resckhe [5] stated that Organizational Citizenship Behavior (OCB) is an individual contribution, more than the role requirement at workplace and rewarded by performance acquisition. The measuring of OCB was developed by Podsakoff and MacKenzie [6] consisting of: behavior to help other coworkers without any coercion (altruism), the performance of prerequisite which is beyond the minimum standard (Conscientiousness), voluntary participation and support towards organizational functions professionally as well as social nature (Civic Virtue), avoid making issue which could disturb work environment (Sportsmanship).

Talking about performance would refer to how to 
measure performance gained by someone or a group of people in an organization, corresponding to his/their task and responsibility to achieve the organization's goals. Performance is an outcome resulted by a function of a work or certain activities during a certain period of time. This opinion is in accordance with the thought of Bernardin and Russel [7] who stated that "Performance is the record of outcome produced on a specific job function or activity during a specified time period". Thus the discussion of performance is a thought of one variable which does not stand alone, but is dependent on other variables, among others Strategic Leadership, Organizational Learning and Organizational Citizenship Behavior.

\section{Literature Review}

\subsection{Strategic Leadership}

An organization always demands leadership to achieve its goals. That's why it needs a leader who can give direction and instruction to the organization members to run their task and authority in an attempt to achieve the organization's mission. Strategic leadership is a process in a group of people. To be able to lead, a leader should do something in a team. Strategic leadership is the ability of someone to anticipate, make vision, maintain flexibility, think strategically and work together with other people to start a change which can bring a better future to the organization. Strategic leadership has six components i.e: determining strategic direction, exploiting and maintaining core competencies, developing human capital, sustaining an effective corporate culture, emphasizing ethical practices, and establishing strategic control. Burns [8] suggested 16 skills which a leader should possess. In this research, five indicators were chosen i.e Visionary, the ability to manage change, the ability to build cohesion and sense of belonging, the ability to think strategically, and the ability to generate trust.

\subsection{Organizational Learning}

Learning no longer means to obtain knowledge, but behavior will change if you learn [4]. Then, learning process occurs when an individual is regularly given room to find out and create the reality of what he is studying about. Therefore the individual becomes a new person for every stage, able to do, understand and live something he has not experienced before, able to have a different perception about the reality encountered and learned, thus become part of the function of a generation with new paradigm. Organizational learning is a process to detect and correct improve faults. Whilst Garvin [3] defined organizational learning as an organizational expertise to create, obtain, interpret, transfer and share knowledge, with the aim to modify the behavior to describe new knowledge and new insight. Khandekar and Sharma [9] defined an organizational learning as an organization providing learning facilities to all organization members to sustainably transform themselves. This research used 5 learning dimensions as suggested by Senge [4] and it was necessary to manifest learning organization, i.e Thinking System; Mental Model; Personal Control; Team Learning and Shared Vision.

\subsection{Organizational Citizenship Behavior}

Organizational Citizenship Behavior can be defined as a free individual behavior, not directly connected with reward system and can increase the effective function of an organization. Contextual behavior not only supporting the core of the behavior itself, but also promoting the growth of the organization socially and psychologically, so the technical core will function. Aldag and Resckhe [5] stated Organizational Citizenship Behavior (OCB) was a deep individual contribution more than the required performance at workplace and rewarded by task performance acquisition. Organizational Citizenship Behavior is a beneficial behavior for an organization, made spontaneously by members and never explicitly instructed in a reward system of a formal organization. The research indicators based on the 5 measuring dimensions of Organizational Citizenship Behavior developed by Podsakoff and MacKenzie [6], as follows: Altruism, Conscientiousness, Sportsmanship, and Civic Virtue.

\subsection{Organizational Performance}

Each organization, both business organizations as well as public organization will attempt to achieve a high performance. In general, organizational performance is a total performance results achieved by an organization, in accordance with the organization's mission. The performance measurement systems help a manager to monitor the business strategic implementation by means of comparing the actual result with the target, and the strategic goals, because it was an answer to the question "what is the result after someone does something " since it measure the quantity and quality of task achievement done by individuals, group or organization.

In performance measuring, dimension and indicators to be used to assess the organization 
success, are needed. Dwiyanto [10] suggested that these were 5 indicators to measure the public bureaucracy performance which would also be used in this research, i.e Productivity, Service Quality, Responsiveness, Responsibility and Accountability.

\subsection{The Relationship between Variables}

\subsubsection{The impact of Strategic Leadership towards Organizational Citizenship Behavior}

Khan et al. [11] did a research about Leadership Styles and Organizational Citizens Behavior in Small and Medium Scale Firms. In this research, it was found out that there occurred a significant change in management of small and medium scale business, mainly after the entry of information technology aspects. Research on business and management justified that employees are activators of the organization resources, therefore were considered as important organizational assets, other available reference justified the assumption that a high citizenship behavior was the most influential factor and contributed much to the success of the company performance. Leadership contribution was basically effective towards employees' commitment and citizenship, and this cannot be ignored.

Another research on the impact of leadership style towards Organizational Citizenship Behavior, among others, was conducted by Lamidi titled "The effect of Transformational Leadership towards Organizational Citizens Behavior, using variables of Organizational Intervening Commitment. This research aimed to test the direct impact of transformational leadership towards organizational commitment, the impact of transformational leadership towards organizational citizens' behavior, and also to test the indirect impact of organizational commitment towards organizational citizens' behavior. The results of this research showed that: (1) there was a direct impact between transformational leadership and organizational commitment, (2) there was a direct impact between transformational leadership and the behavior of the organization members, (3) there was a direct impact between the organizational commitment and organizational

H1: Strategic Leadership has a significant impact towards Organizational Citizenship Behavior

\subsubsection{The Impact of Organizational Learning on Organizational Citizenship Behavior}

Somech and Dranch-Zahavy in Exploring Organizational Citizens Behavior From An Organizational Perspective: The Relationship between Organizational learning and Organizational
Citizenship Behavior, stated that the main aim of this research is to study the problems of Organizational Citizenship Behavior within the context of multi dimension perspective phenomenon specifically to observe the relation between organization learning culture among structures, learning value, and OCB. The result of this research showed that all groups have a very significant relationship, and in the group relationship generally support the ideas that even though OCB is an individual behavior in an organization, the organization members still had the tendency to be involved in organizational behavior. This research gave contribution to arguments that organizational behavior could be seen as an internal organization phenomenon. Finally it was concluded that variables in organizational learning have a position relationship with OCB dimension.

Another research on the impact of Organization Learning on Organizational Citizenship Behavior was conducted by Arma et.al. in Learning Organization in Implementation New Public Service at Palu Local Government Indonesia, found out that all measurement conducted showed positive and significant impact of Learning Organization towards OCB. The result of this research could be utilized to increase local government public service, specifically in learning Organization Application.

$\mathrm{H} 2$ : Organizational Learning has significant impact in positive direction towards Organizational Citizenship Behavior.

\subsubsection{The Impact of Organizational Citizenship Behavior towards Organizational Performance}

Work environment keeps changing, therefore leaders are required by all means to find ways to increase and, reinforce the internal organization work environment. Organization members are significant resources and their honest behavior, taking part in organization activities, in other words, doing trivial activities but beneficial to their coworkers in the organization, is required. Organization members' behavior is a fundamental element for an organization in order to be successful. Organizational performance depends on the employee. On that account, an employee management is very important. In other words it can be said that it is a necessity for an organization to know and understand the employee, to ensure the condition in internal as well as external activities.

Faramarzi, Azizi and Parver in The Relationship between Organizational Citizenship Behavior and Organizational Performance of Mellat Bank Personnel in Tehran showed that the research was conducted with the aim to prove a positive and 
significant relationship between $\mathrm{OCB}$ and its dimension (altruism, generosity, civility, job consciousness, and social etiquette), with the organizational performance.

Romle et.al. in The relationship between Organizational Citizenship Behavior and High Performance Organization from the Perspective of the Higher Education Institution in Malaysia said that OCB and Organizational Performance had a very strong relationship and high correlation between them. Based on contribution and perspective theory, it is expected that this study could contribute a significant knowledge specifically related to organizational behavior of learners. This research also emphasized on the discovery of high organizational performance through organizational successful factors, such as management quality, the fairness, future orientation, development or organizational quality of the organization members.

Kolade et.al in Organizational Citizenship Behavior, Hospital Corporate Image and Performance showed that there is a positive correlation among variables. Hypothesis one described the correlation between OCB and Performance; this hypothesis showed that there was a significant and statistic correlation between OCB and performance the findings of the validated hypothesis revealed that OCB facilitated hospital performance acquisition. This meant that understanding and cooperation among coworkers, running the extra work without delay and complaints, punctuality, being volunteers, using organizational resource efficiently, sharing ideas and representing organization in a positive way, will increase service efficiency, patients', satisfaction, patients willingness to revisit and recommend to people at large, which will increase the organizational performance, the research of Kolade and Yan stated that Organizational Citizenship Behavior beneficial behavior for an organization, made spontaneously by members and was never explicitly and directly instructed in a reward system of a formal organization..

H3: Organizational Citizenship Behavior has a positive significant to Organizational Performance

\subsubsection{The Impact of Strategic Leadership to Organizational Performance}

Pazireh et al. [12] conducted research Evaluation the Role of Strategic Leadership in Organizational Performance suggested that Strategic Leadership would affect the Organization Performance through work understanding and environment and this would build interaction among workers. These were in line with employee's activity to determine strategic direction, facilitating goal achievement, and doing the work through core competencies development, developing human resources as competitive advantages, maintaining the company culture effectively to promote competition spirit, building strategic control, to create and achieve the optimal organization performance.

Serfontein and Hough [13] in Nature of Relationship between Strategic Leadership, Operational Strategy and Organizational Performance suggested that the main contribution of this research was that Strategic Leadership has a direct and positive impact on operational advantages and performance in business organization in South Africa. Managerial implication of established model in this research was that leaders and executives in a business organization could implement strategic leadership of high performance to increase strategic orientation and the best operationalization in their organization. This research was in accordance with strategic leadership theory in achieving organizational performance.

H4: Strategic Leadership has significant and positive impact on Organization Performance.

\subsubsection{The Impact of Organizational Learning to Organizational Performance}

Organization nowadays is run in a rapid and ever changing environment. Organization Learning provides a dynamic culture to every organization. For this reason, organization learning is relevant and could effectively push the organization to adapt themselves to rapid changes. In order to be successful and have an advantage in competition, the present and future organization must become organizational learning.

Ratna et.al. in Impact of Learning Organization on Organizational Performance in Consulting Industry conducted a study to analyze the impact of organizational learning on organizational performance. They suggested that the companies which invest more would gain higher advantages of organizational performance, financially or nonfinancially. It was largely acknowledged that the development of organizational learning was a fundamental factor to achieve the competitive advantages. After being analyzed it was found out that there was a positive correlation between organizational learning and organizational performance. Thus, from the research, it could be concluded that there was a positive and high correlation between organizational learning and organizational performance. 
Hussein et. al. in Learning Organization and its Effect on Organizational Performance and Organizational Innovativeness: A Proposed Framework for Malaysian Public Institutions of Higher Education stated that it had become more and more important for an organization to adopt learning orientation, and such a case could help giving contribution to the success of the organization. However, the learning ability cannot be gained easily and naturally in an organization, therefore it is important for the organization to ensure the allocated human resource and efforts done to conduct learning organization. Accordingly, it is important that public institutions as well as other organizations should become a learning organization to guarantee that the organization goals could be achieved. As stated above, many researchers have shown that learning organization gives a great impact on organizational performance. Research conducted by Khandekar \& Sharma [9] titled Organizational Learning and Performance aim to show that the organizational learning had become more significant for organizational performance. This research found out that organizational learning, through human resources activity, had a positive relationship with financial performance. The correlation between performance measurements with organizational learning was found to be positive and significant. This was due to the fact that human resources play an important role in building and maintaining the philosophy of organizational learning where human resources design the system and process. Systems are needed where learning is required. Ideas only emerge from individuals, so the organizational learning is needed in the level of individuals, group of people and organization. Accordingly managerial activities will have to focus and spread about the development of the sources of organizational knowledge; because employee's knowledge plays an important role in labor power.

H5: Organizational Learning gives a positive and significant impact to Organizational Performance.

\section{Research Method}

Research Framework

In this research, a conceptual framework is described in the following pictures:

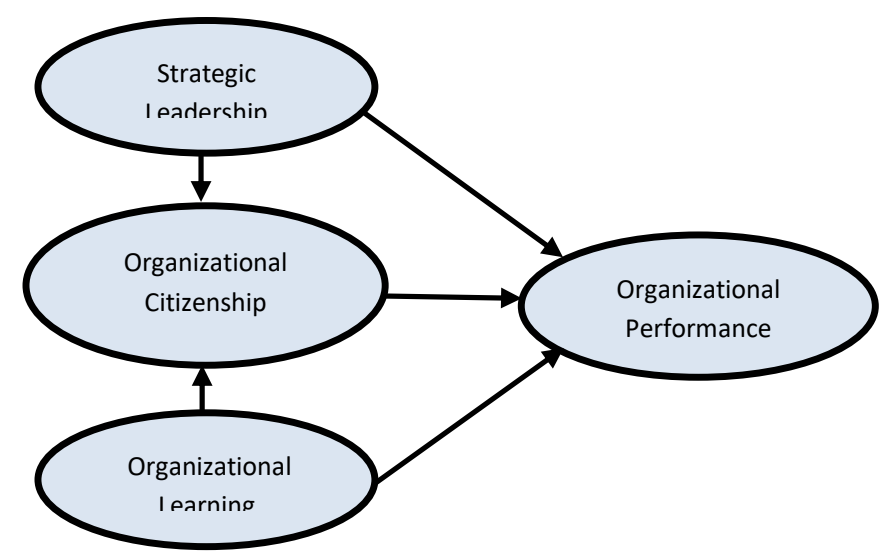

\subsection{Research Instruments}

Research variables basically are whatever determined by the researcher to be studied and concluded. Variables can be symbols or numbers on which numbers or value [16] are attached. Another meaning of variable is research object, or what become points of attention in a research, Arikunto [17]. In this research there were two variable groups i.e Exogenous Constructs and Endogenous Constructs. Exogenous Constructs are also known as source variables or independent variables, variables which are not predicted by other variables in a model. Those variables could be explained as follows:

\section{Exogenous Variables of Strategic Leadership (X1)}

2. Exogenous Variables of Organizational Learning (X2)

3. Intervening Variables of Organizational Citizenship Behavior (Y1)

4. Endogenous Variables of Organizational Performance (Y2)

The first exogenous variable in this research was strategic leadership. Indicator used and would be measured in this research was as suggested by Burns [8], mentioning that the strategic leadership indicators were visionary ability (X1.1), the ability to manage change (X1.2), the ability to build cohesion and sense of belonging (X1.3), ability to think strategically (X1.4) and the ability to build trust (X1.5).

The second exogenous variable was organization learning with theoretical based indicator developed by Sange [4], covering: Thinking System (X2.1), Mental Model (X2.2), Personal Skill (X2.3), Team Work (X2.4) and skill to share vision (X2.5).

Endogenous variable to be measured would be: Organizational Performance with theoretical based indicator suggested by Dwiyanto [10] covering: Productivity (Y2.1), Service Quality (Y2.2), 
Responsiveness (Y2.3), Responsibility (Y2.4) and Accountability (Y2.5).

Intervening Variable that would be examined was Organizational Citizenship Behavior based on Podsakoff and Mckenzie's opinion [6], covering: Altruism (Y1.1), Conscientiousness (Y1.2), Sportsmanship (Y1.3), and Civic virtue (Y1.4).

\section{Hypothesis}

Hypothesis proposed in this research was validated by using theory and data obtained from research samples. Testing tools used to test the hypothesis in this research was statistical utilizing PLS.

H1: Strategic Leadership had a significant and positive impact on Organizational Citizenship Behavior

$\mathrm{H} 2$ : Organizational Learning had a significant and positive impact on Organizational Citizenship Behavior

H3: Organizational Citizenship Behavior had a significant and positive impact on Organizational Performance

H4: Strategic Leadership had a significant and positive impact on Organizational Performance

H5: Organizational Learning had a significant and positive impact on Organizational Performance

\subsection{Population and Sampling}

Population is a group of object being observed in a research, consisting of object having certain quality and characteristics as set by the researcher to study and conclude. Population is combination of all elements, events, things or people having the same characteristics one of which the researchers focuses because it is considered to be a universal research (Ferdinand, 2014:171). Populations used in this research were 19 Ministries in the 6th Timor-Leste government. Respondents were all Director Generals of the Ministries.

In this research the sample measurement was determined by using Yamane approach in Ferdinand (2014) as follows:

$$
\begin{aligned}
& \mathrm{n}=\mathrm{N} /\left(1+\mathrm{Nd}^{2}\right) \\
& \mathrm{n}=\text { samples numbers } \\
& \mathrm{N}=\text { number of population } \\
& \mathrm{d}=\text { precision fixed on percentage leniency of }
\end{aligned}
$$
inaccuracy due to faulty sampling which can still be tolerated. In this research d value $=5 \%$, so the number of samples used by the researcher was

$$
\mathrm{n}=19 /\left(1+19(0.05)^{2}\right)=18.13 \approx 18
$$

From the above sample determination formula sample measurement to be used are 18 Ministries. Sampling technique used in this research was carried out by means of the type of Non Probability
Sampling with purposive sampling technique as suggested by Ferdinand [14] and Sugiyono [15]. In this research, the specified respondents consisted of Director Generals reaching a total of 40 persons.

\subsection{Method of Data Analysis}

In this research, hypothesis testing used quantitative method with statistical validation with Partial Least Square (PLS) data analysis model. To answer the items related with level of inclination, of some variables in their research as mentioned before, the form of Likert scale questions was used, to enable the respondents answer various levels of questions (strongly agree, agree, neutral, disagree, strongly disagree). The scale offered would determine the scale of each question from respondent. The possible biggest score was 5 and the smallest possible score was 1 or vise versa

\section{Findings}

The analysis used to answer the hypothesis in this research was Structure Equation Model Partial

\begin{tabular}{|c|c|c|c|c|c|c|c|}
\hline \multirow[t]{2}{*}{ Impact } & \multirow{2}{*}{$\begin{array}{l}\text { Coef } \\
\text { Orginal }\end{array}$} & \multicolumn{2}{|c|}{$\begin{array}{c}\text { (Bootstrap } \\
B=100)\end{array}$} & \multicolumn{2}{|c|}{$\begin{array}{c}\text { (Bootstrap } \\
\mathrm{B}=\mathbf{3 0 0})\end{array}$} & \multicolumn{2}{|c|}{$\begin{array}{c}\text { (Bootstrap } \\
\mathrm{B}=500)\end{array}$} \\
\hline & & Coef. & t-test & Coef. & t-test & Coef. & t-test \\
\hline $\begin{array}{l}\text { Strategic Leadership } \\
\text { (X1) } \rightarrow \text { Organizational Citizenship } \\
\text { Behavior (Y1) }\end{array}$ & 0.251 & 0.256 & 4.810 & 0.264 & 8.728 & 0.247 & 6.001 \\
\hline $\begin{array}{l}\text { Organizational Leaming } \\
\text { (X2) } \rightarrow \text { Organizational Citizenship } \\
\text { Behavior (Y1) }\end{array}$ & 0.360 & 0.375 & 5.066 & 0.351 & 6.198 & 0.363 & 7.333 \\
\hline $\begin{array}{l}\text { Organizational Citienship } \\
\text { Behavior Y1) } \rightarrow \text { Organizational } \\
\text { Performance (Y2) }\end{array}$ & 0.349 & 0.336 & 4.985 & 0.359 & 8.531 & 0.355 & 9.255 \\
\hline $\begin{array}{l}\text { Strategic Leadership }(\mathrm{X} 1) \rightarrow \\
\text { Organizational Performance }(\mathrm{Y} 2)\end{array}$ & 0.384 & 0.412 & 4.788 & 0.400 & 11.108 & 0.371 & 11.263 \\
\hline $\begin{array}{l}\text { Organizational Leaming } \\
\text { (X2) } \rightarrow \text { Organizational } \\
\text { Performance (Y2) }\end{array}$ & 0.262 & 0.264 & 4.884 & 0.255 & 5.446 & 0.272 & 6.181 \\
\hline
\end{tabular}
Least Square (PLS). Hypothesis test showed a result of structural coefficient (Inner Weight) with a complete significant values as shown at the Table below:

Based on the above table, the interpretation of each coefficient track was as follows:

1.Hypothesis 1: Strategic Leadership (X1) had a positive and significant impact on Organizational Citizenship Behavior (Y1). This could be seen from the positively marked coefficient track of 0,251 with T-Statistic value of 6.001 which was bigger than t-table $=1,96$. Accordingly, Strategic Leadership (X1) gave a direct impact on Organizational Citizenship Behavior (Y1) of 0,251 , which meant that if there was any increase of Strategic Leadership (X1), there would also be an increase of Organizational Citizenship Behavior (Y1). Based on the above hypothesis 1 could be accepted.

2.Hypothesis 2: Organizational Learning (X2) gave 
a positive and significant impact on Organizational Citizenship Behavior (Y1). This could be seen from the positively marked coefficient track of 0,360 with T-Statistic value of 7.333 which was bigger than $\mathrm{t}$-table $=1,96$. Accordingly, Organizational Learning (X2) had an impact on Organizational Citizenship Behavior (Y1) of 0,360 , which meant that any increase of Organizational Learning (X2) would also increase Organizational Citizenship Behavior (Y1). Based on this, hypothesis 2 could be accepted.

3.Hypothesis 3: Organizational Citizenship Behavior (Y1) gave a positive and significant impact on Organizational Performance (Y2). This could be seen from the positively marked coefficient track of 0,349 with T-Statistic value of 9.255 which was bigger than t-table $=1,96$. Accordingly, Organizational Citizenship Behavior (Y1) gave a direct impact on Organizational Performance (Y2) of 0,349, which meant that any increase of Organizational Citizenship Behavior (Y1) would also increase Organizational Performance (Y2). Based on this, hypothesis 3 could be accepted.

4.Hypothesis 4: Strategic Leadership (X1) had a positive and significant impact on Organizational Performance (Y2). This could be seen from the positively marked coefficient track of 0,384 with T-Statistic value of 11.263 which was bigger than t-table $=1,96$. Therefore, Strategic Leadership (X1) gave a direct impact on Organizational Performance (Y2) of 0,384 , meaning that any increase of Strategic Leadership (X1) would also increase Organizational Performance (Y2). Based on this, hypothesis 4 could be accepted.

5.Hypothesis 5: Organizational Learning (X2) had a positive and significant impact on Organizational Performance (Y2). This could be seen from the positively marked coefficient track of 0,262 with T-Statistic value of 6.181 which was bigger than t-table $=1,96$. Accordingly, Organizational Learning (X2) gave impact on Organizational Performance (Y2) of 0,262, which meant that any increase of Organizational Learning (X2) would also increase Organizational Performance (Y2). Based on this, hypothesis 5 could be accepted.

\section{Conclusions}

Based on the result of study analysis, and discussion, the following conclusion can be drawn: Strategic Leadership has a positive and significant impact on Organizational Citizenship Behavior. Therefore Strategic Leadership has a direct impact on Organizational Citizenship Behavior, which means that any increase of Strategic Leadership will increase Organizational Citizenship Behavior. Organizational Learning gives a positive and significant impact on Organizational Citizenship Behavior. Therefore Organizational Learning gives a direct impact on Organizational Citizenship Behavior, which means any increase of Organizational Learning will affect increase of Organizational Citizenship Behavior. Organizational Citizenship Behavior has a positive and significant impact on Organizational Performance. Therefore Organizational Citizenship Behavior gives a direct impact on Organizational Performance, which means any increase of Organizational Citizenship Behavior will also increase Organizational Performance. Strategic Leadership has a positive and significant impact on Organizational Performance. Therefore Strategic Leadership gives a direct impact on Organizational Performance, which means that any increase of Strategic Leadership will increase Organizational Performance. Organizational Learning has a positive and significant impact on Organizational Performance. Therefore Organizational Learning gives a direct impact on Organizational Performance, which means that any increase of Organizational Learning will affect the increase of Organizational Performance

\section{References}

[1] Waterman, R. Jr., Peters, T., and Phillips, J. R. Structure Is Not Organization in Business Horizons, Vol. 23, No. 3, June 1980, pp 14-26.

[2] Wright, P. M., McMahan, G. C. "Theoretical Perspectives for Strategic Human Resource Management", Journal of Management, Vol. 18, 1992, pp. 295321.

[3] Garvin, D. A. Learning in Action: A Guide to Putting: The Learning Organizational to Work, 2000, Boston: Harvard Business School Press.

[4] Senge, P. M. The Fifth Discipline: The Art and Practice of the Learning Organization, 1994, New York: Doubleday.

[5] Aldag, R., and Reschke, W. Employee Value Added, 1997, New-York: Center for Organizational Effectiveness Inc.

[6] Podsakoff and McKenzie, Organizational Citizenship Behavior: its Nature, Antecedents and Concequences, 1997, Sage Publication: Thousand Oaks California. 
[7] Bernardin, H and Russel, E. Human Resource Management: An Experimental Approach, 1993, Singapore: McGraw-Hill Inc.

[8] Burns, P. Corporate Entrepreneurship Building the Enterpreneurial Organization, Second edition, 2008, NY: Plagrave Mcmilan.

[9] Khandekar, A. and Sharma, A. Organizational Learning and Performmance: Understanding Indian Scenario in Present Global Context, Education and Training, 2006, Vol.48 No.8/9, pp.682-293.

[10] Dwiyanto, A. Analisis Biaya Manfaat. Pusat Penelitian Kependudukan, 2006, Yogyakarta: Universitas Gadjah Mada.

[11] Khan, N. R., Ghouri, A. M., and Awang, M. "Leadership Styles and Organizational Citizenship Behavior in Small and Medium Scale Firms". International Refereed Research Journal, 2013, Vol. IV, 2.

[12] Pazireh, M., Akhlagh, E. M., and Akbar, M. "Evaluation the Role of strategic Leadership in Organizational Performance". Universal Journal of Management and Social Science, 2014, Vol 4, No. 9.

[13] Serfontein, K., and Hough, J., Nature of The Relationship between Strategic Leadership, Operational Strategy and Organisational Performance. SAJEMS No.4.

[14] Ferdinand, A. Metode Penelitian Manajemen, Pedoman Penelitian untuk Penulisan Skripsi, Tesis dan Disertasi Ilmu Manajemen, 2014, UNDIP Press, edisi 5.

[15] Sugiyono. Metode Penelitian Administrasi, 2013, Bandung: Alfabeta, Bandung.

[16] Kerlinger, F, N., Foundations of Behavioral Research. Third Edition. Terjemahan oleh L.R. Simatupang, 1993, Yogyakarta, Gadjah Mada University Press

[17] Arikunto, S. Prosedur penelitian, Suatu Pendekatan Praktek. Edisi Revisi V, 2002, Jakarta: Rineka Cipta..

\section{Author Profile}

Fernando Dias Gusmão currently is a Dr (cand.) in Postgraduate School of Universitas Katolik Widya
Mandala Surabaya and lecturer at Universidade da Paz (UNPAZ) Timor-Leste.

Budiman Christiananta, MA., Ph.D., Drs. Ec is a lecturer at Postgraduate School of Universitas Katolik Widya Mandala Surabaya.

Dr. Lenna Ellitan is a lecturer at Postgraduate School of Universitas Katolik Widya Mandala Surabaya. 